\title{
PHARMACODYNAMICS EFFECT OF METHYLPREDNISOLONE TABLETS ON THE SERUM CONCENTRATION OF ANNEXIN A1: IN VIVO COMPARATIVE STUDY BETWEEN GENERIC AND INNOVATOR DRUG
}

\author{
HANSEN NASIF ${ }^{1,2 *}$, HENNY LUCIDA ${ }^{3}$, YANWIRASTI YANWIRASTI ${ }^{4}$, YUFRI ALDI ${ }^{2}$, YORI YULIANDRA ${ }^{2}$ \\ ${ }^{1}$ Department of Biomedical Sciences, Faculty of Medicine, Andalas University, Padang, Indonesia. ${ }^{2}$ Department of Pharmacology and \\ Clinical Pharmacy, Faculty of Pharmacy, Andalas University, Padang, Indonesia. ${ }^{3}$ Department of Pharmaceutics, Faculty of Pharmacy, \\ Andalas University, Padang, Indonesia. ${ }^{4}$ Department of Anatomy, Faculty of Medicine, Andalas University, Padang, Indonesia. \\ Email: hansennasif@phar.unand.ac.id
}

Received: 01 October 2018, Revised and Accepted: 30 November 2018

ABSTRACT

Objective: The aims of this study were to investigate the comparative pharmacodynamics effect of methylprednisolone (MP) innovator, MP branded generic, and MP generic products to the serum concentration of annexin A1 (AnxA1).

Methods: It was conducted by two-way crossover design in male rabbits. AnxA1 was measured at $0,0.5,1,2,3,5,7$, and $9 \mathrm{~h}$ after the administration of the drugs. The peak concentration $\left(\mathrm{C}_{\max }\right)$, the time at which the peak concentration was achieved $\left(\mathrm{T}_{\max }\right)$, and the area under the plasma concentrationtime curve (AUC) were also determined.

Results: The highest concentration and widest AUC of AnxA1 were obtained in MP innovator drug. MP innovator and branded generic reaches the peak time $\left(\mathrm{T}_{\max }\right)$ at the third $3^{\text {rd }} \mathrm{h}$, while the MP generic reaches the peak time at the $5^{\text {th }} \mathrm{h}$. The results showed that there was no significant difference in the serum concentration of AnxA1 between MP tablets after analyzed with a one-way analysis of variance.

Conclusion: It could be concluded that the innovator drug of MP tablet gave the same effect on the serum concentration of AnxA1 than its generic counterparts, but an onset of action MP innovator and branded generic is faster than the generic product.

Keywords: Annexin A1, Branded generic, Generic, Innovator drug, Methylprednisolone.

(c) 2019 The Authors. Published by Innovare Academic Sciences Pvt Ltd. This is an open access article under the CC BY license (http://creativecommons. org/licenses/by/4. 0/) DOI: http://dx.doi.org/10.22159/ajpcr.2019.v12i1.30010

\section{INTRODUCTION}

The research on the topic of branded and generic drug comparison always provides an interesting perspective among pharmacy stakeholders. A one-sided assertion from drug manufacturers about the equivalent quality of generic drugs with the innovator products raises the pros and cons in the community, including the health-care providers. The uses of generic drugs, despite varying, are still very popular across the globe. Generic drug prescriptions in the United States are counted $89 \%$ and cause only $26 \%$ of the total drug cost of the country [1]. In the United Kingdom, the uses of generic drugs were counted $83 \%$. Nonetheless, this number is reported to vary widely among European countries not only in the number of uses but also in terms of price and market share [2]. In addition, the generic drugs are only prescribed in $15 \%$ of all prescriptions in Italy [3].

The use of generic drugs as the substitutes for branded drugs has been widely recognized in developed countries as an effort to reduce the costs of health care [4]. In Indonesia, generic drug use has been stated in the Health Ministry Regulation No. HK.02.02/MENKES/068/I/2010 in 2010. In this decree, the government obliged hospitals and government health service facilities to provide, prescribe, and use generic drugs [5].

The existing studies on the comparative quality of branded and generic drugs showed different results. The study was conducted by Brown et al. who compared that the use of branded and generic drugs of alendronate in osteoporosis found a lower efficacy of generic drugs as compared to branded products [6]. Another comparative study on amoxicillin conducted by Del Tacca et al. found that the generic product was not bioequivalent to its innovator product [7]. In addition, Garg et al. reported that the incidence of acute adverse effects of the branded drug zoledronic acid was only $35.06 \%$, and it is lower than a generic product that reached $55.88 \%$ [8]. However, some contrary results have also been reported. Diaz et al. who conducted an in vitro comparative antimicrobial activity of vancomycin with different brands revealed that there was no significant difference between their potencies [9]. Similar results were also obtained by Cooper-Dehoff and Elliott who compared patent and generic drugs of some blood pressure lowering agents that included beta-blockers, diuretics, and calcium antagonists [10]. Some other studies on clopidogrel and candesartan tablets also reported bioequivalence between their patent and generic products [11,12]

Methylprednisolone (MP) is a corticosteroid anti-inflammatory drug classified to glucocorticoid. This drug is commonly used to treat many different conditions such as skin problems, allergic reactions, arthritis, lupus, and other disorders [13]. In Indonesia, the generic products for MP can be priced 10 times cheaper than the innovator drug (Medrol ${ }^{\circledR}$, produced by Pfizer). This disparity brings a big question on the quality and bioequivalence of drugs, in general, not only to consumers but also to the health-care practitioners $[14,15]$.

The bioequivalence study between innovator and generic drugs is mostly conducted by investigating the pharmacokinetic profile of the drug molecules in the circulatory system [16,17]. Another approach that can be useful to compare their quality is by involving the pharmacodynamics aspect of the drug. For MP, we hypothesized that the serum concentration of annexin A1 (AnxA1) would be a good indicator for such purpose. AnxA1 is an anti-inflammatory protein that is stimulated by MP and considered as the target molecule of corticosteroids in inhibiting the formation of eicosanoids. This protein is exposed to cells and tissues treated with glucocorticoids as a result of 
their pharmacodynamics process. Moreover, it has been found to mimic the action of glucocorticoids in some in vitro and in vivo systems [18,19]. Further investigation and a comparative study of innovator-generic drugs that consider the pharmacodynamics aspect for MP have not been reported yet. Based on that situation, this study was conducted to compare the pharmacodynamics effect of innovator, branded, and generic drugs of MP tablets to the serum concentration of AnxA1.

\section{METHODS}

\section{Time and place}

The research was conducted in October 2017-December 2017. The treatment to the rabbit, taking a sample of blood, and serum making were conducted at Serology and Immunology Laboratory, Faculty of Pharmacy, Andalas University. Serum testing with enzyme-linked immunosorbent assay (ELISA) kit was conducted at Biomedical Laboratory, Faculty of Medicine, Andalas University.

\section{Drugs and chemicals}

Branded generic and generic tablets of MP were purchased from a local pharmacy, while the innovator drug $\left(\mathrm{Medrol}^{\circledR}\right)$ was a product of Pfizer (Jakarta, Indonesia). Distilled water and ethanol 70\% were purchased from Bratachem (Jakarta, Indonesia). Rabbit AnxA1 ELISA kit (Cat. No E0122Ra) was purchased from BT-Lab (Shanghai, China). All materials were used as received.

\section{Animal preparation and drug administration}

Six male New Zealand white rabbits aged 6 months and weighed $2.7 \mathrm{~kg}$ were acclimatized under normal laboratory condition for 1 week in 12/12 light-dark cycle provided standard fed and drinking water ad libitum. The rabbits were divided into three groups receiving three different MP tablets: MP innovator $\left(\mathrm{Medrol}^{\circledR}\right)$, MP branded generic, and MP generic in the dose of $4 \mathrm{mg}$ (history of the drugs is presented in Table 1). Each animal received all three drugs with a 1-week washout period (Table 2). The blood sampling was taken through the orbital vein in $0,0.5,1,2,3,5,7$, and $9 \mathrm{~h}$ after the treatment. These specimens were centrifuged at $3000 \mathrm{rpm}$ for $20 \mathrm{~min}$. All serums obtained were stored at $-20^{\circ} \mathrm{C}$ for further analysis.

\section{AnxA1 determination}

The serum concentration of AnxA1 was determined from a total of 144 serum samples using ELISA. The absorbance was detected at $\lambda 450 \mathrm{~nm}$ (BioRad Laboratories, CA, USA). In addition, the peak concentration $\left(\mathrm{C}_{\max }\right)$, the time at which the peak concentration is achieved $\left(\mathrm{T}_{\max }\right)$, and the area under the plasma concentration-time curve (AUC) were also calculated.

Table 1: Animal grouping and treatment sequence

\begin{tabular}{llll}
\hline \multirow{2}{*}{ Group } & \multicolumn{2}{l}{ Treatment of MP tablet* } \\
\cline { 2 - 4 } & Round 1 & Round 2 & Round 3 \\
\hline 1 & MP innovator & $\begin{array}{l}\text { MP branded } \\
\text { generic }\end{array}$ & MP generic \\
2 & $\begin{array}{l}\text { MP branded } \\
\text { generic }\end{array}$ & MP generic & MP innovator \\
3 & MP generic & MP innovator & $\begin{array}{l}\text { MP branded } \\
\text { generic }\end{array}$ \\
\hline *Each treatment round was undertaken with 1-week washout period.
\end{tabular}

*Each treatment round was undertaken with 1-week washout period.

MP: Methylprednisolone

\section{Ethical clearance}

All of the ethical clearance protocols of this study were approved by the Ethics Committee from the Faculty of Medicine, Andalas University No. 338/KEP/FK/2017 (October 2, 2017).

\section{Data analysis}

The comparative analysis was conducted using one-way analysis of variance (ANOVA) MP innovator as the control. It was analyzed with Statistical Package for the Social Sciences (SPSS) for Windows (IBM, New York, USA).

\section{RESULTS AND DISCUSSION}

The bioequivalence study is very crucial to compare two products with the same active pharmaceutical ingredient and the same dosage form which are bioequivalent despite different formulations. This bioequivalence is a good indicator to represent the therapeutic equivalence of both products in terms of efficacy and tolerability [10]. The good result of the bioequivalence study may allow the manufacturer to waive the in vivo study according to the waiver policy of the Biopharmaceutics Classification System [20]. However, further in vivo studies in experimental animals are, sometimes, required to follow up the comparative in vitro dissolution tests. Many physiological factors are likely to interfere with the fate of the drugs in the body. These include their transit time in the gastrointestinal tract before reaching their sites of absorption and their residence time as well, their stability in the luminal fluid, and the first pass effect that may alter the metabolism of the drug [21].

The comparative pharmacodynamics effect between innovator and generic products of MP tablets in the present study was investigated in vivo. This in vivo model was considered to emulate better pharmacokinetics circumstances in the human body as compared with only in vitro dissolution profile. To investigate and compare the pharmacodynamics effect of MP products, we used the serum concentration of AnxA1, a protein that plays a role in the resolution of inflammation, as the biochemical parameter of the drugs' performance. In addition, some parameters such as peak concentration $\left(\mathrm{C}_{\max }\right)$, time $\left(\mathrm{T}_{\max }\right)$, and AUC of this protein were explored.

AnxA1, previously known as lipocortin-1, is a protein regulated by glucocorticoids that inhibit the activity of phospholipase A2. This protein is also reported to inhibit the cyclooxygenase- 2 expression and, thus, blocks the production of prostaglandins and other proinflammatory mediators. AnxA1 is considered as an effector molecule in the mechanism of action of the anti-inflammation effect of steroid drugs [22-24]. In addition, AnxA1 is also believed to be responsible for the regulation of the immune system. Furthermore, this protein may be potential for the therapeutic target and biomarker in several diseases, including cancer and neurodegenerative disorders [25]. The glucocorticoid drugs such as MP exhibit their pharmacodynamics effect through several inflammatory pathways. One of their mechanisms of action is by inducing and activating AnxA1 [26]. Since this protein plays a major role in the biochemical process of inflammatory activity of the corticosteroid drugs, the fate of this molecule in the circulatory system is a reliable parameter to determine the performance of the drug.

Based on Table 3, the concentration of AnxA1 of each drug is $15.57 \pm 0.61 \mathrm{ng} / \mathrm{ml}, 14.59 \pm 0.31 \mathrm{ng} / \mathrm{ml}$, and $14.48 \pm 0.11 \mathrm{ng} / \mathrm{ml}$. The higher concentration that consists of the drug could give the stronger

Table 2: History of selected MP tablets

\begin{tabular}{lllll}
\hline Type of MP tablet & Batch number & Expiration date & Price per tablet (USD)* & Percentage price differential with the innovator \\
\hline MP innovator & 940C8 & March 19 & 0.37 & - \\
MP branded generic & TPF36346 & May 20 & 0.19 & 50 \\
MP generic & ITPL00845 & October 18 & 0.04 & 10 \\
\hline
\end{tabular}

*Converted from IDR to USD. MP: Methylprednisolone 
effect as an anti-inflammatory. The result of ANOVA showed on Table 4 refers that there are no significant differences of serum concentration AnxA1 between innovator drug, branded generic drug, and generic drug.

Fig. 1 shows a better effect of innovator product of MP tablet as compared with its generic products to the serum concentration of AnxA1. The trend of serum concentration of AnxA1 during $9 \mathrm{~h}$ of observation showed a similar baseline before the administration of MP tablets. A clear distinction starts to appear after an hour of observation, in which MP innovator shows higher AnxA1 concentration reached in a faster period than that in generic products.

The MP of innovator drug showed the same peak time as the MP of branded generic drug which reaches the peak time at the $3^{\text {rd }} \mathrm{h}$, while the MP of the generic drug reaches the peak time at the $5^{\text {th }} \mathrm{h}$. The difference of innovator $\mathrm{T}_{\max }$ MP with generic means a slightly late peak effect of drugs. This is also one of the triggers of controversy in the community and health professionals with a statement that we often hear that the effects of generic drugs are slower to appear than the innovator. This $\mathrm{T}_{\max }$ profile can actually answer the controversy. The delay in $\mathrm{T}_{\max }$ is actually quite vital if it occurs in life-saving drugs as well as other drugs that require fast effects. It is happening because of the quality of raw materials, physicochemical properties, and the process of drugs manufacturing that could affect the phase.

The overall performance of solid dosage forms, for example, tablets in the living tissue depends on the quality of the raw materials [27]. The

Table 3: Comparative parameters of AnxA1 between innovator drug of MP and its generic tablets

\begin{tabular}{llll}
\hline Parameter & $\begin{array}{l}\text { MP } \\
\text { innovator }\end{array}$ & $\begin{array}{l}\text { MP branded } \\
\text { generic }\end{array}$ & $\begin{array}{l}\text { MP } \\
\text { generic }\end{array}$ \\
\hline $\mathrm{C}_{\max }(\mathrm{ng} / \mathrm{ml})$ & $15.56 \pm 0.61$ & $14.59 \pm 0.31$ & $14.48 \pm 0.11$ \\
$\mathrm{~T}_{\max }(\mathrm{h})$ & 3 & 3 & 5 \\
$\mathrm{AUC}\left(\mathrm{ng}^{*} \mathrm{~h} / \mathrm{ml}\right)$ & 111.88 & 108.06 & 103.21 \\
\hline
\end{tabular}

$\mathrm{C}_{\max }$ : The peak concentration; $\mathrm{T}_{\max }$ : The time at which $\mathrm{C}_{\max }$ is achieved; AUC: Area under the plasma concentration-time curve; $\mathrm{n}=144$. AnxA1: Annexin A1, MP: Methylprednisolone

Table 4: The result of the ANOVA test of AnxA1 between innovator drug of MP and its generic tablets $(n=48)$

\begin{tabular}{llllll}
\hline Annexin & Sum of square & df & Mean $^{2}$ & F & Significant \\
\hline Between groups & 7.139 & 2 & 3.570 & 1.123 & 0.334 \\
Within groups & 143.087 & 45 & 3.180 & & \\
Total & 150.226 & 47 & & & \\
\hline
\end{tabular}

ANOVA: Analysis of variance, AnxA1: Annexin A1, MP: Methylprednisolone

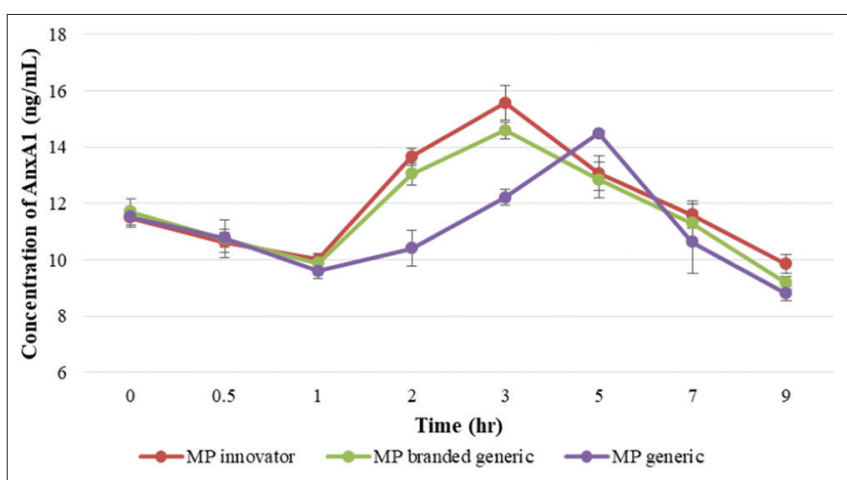

Fig. 1: The trend of serum concentration of annexin A1 during $9 \mathrm{~h}$ of observation after the administration of methylprednisolone tablets $(n=144)$ quality is not only influenced by the active pharmaceutical ingredients but also by the inactive substances called excipients. The pharmaceutical excipients in tablets may include fillers, binders, and disintegrants. Inconsistency in fillers, for instance, may trigger the variability in dosages. Meanwhile, binders play an important role in the formation of granules with good flow properties and tablet compression [28]. Variation in the composition of these excipients that present among drug products may result in different biopharmaceutical process before the absorption of active molecules. In addition, some excipients in the formulation are also reported to alter the activity of intestinal transport proteins and thus can influence the absorption of the drug molecules. Therefore, the pharmaceutical excipients can alter the bioavailability and, in turn, the pharmacological effect of the drugs [29].

According to the US Food and Drug Administration, a generic drug product is "one that is comparable to an innovator drug product in dosage form, strength, route of administration, quality, performance characteristics, and intended use [30]." The definition and classification of the generic pharmaceutical products are reported to be different across the globe, contrary with the innovator drugs that are unvaryingly interpreted as drugs produced for the $1^{\text {st }}$ time by the patent holders that receive first approval. In Indonesia, for example, the generic drugs discriminate into two different types: Branded generic and official generic. Branded generic drugs are those sold under trademarked names given by the manufacturers, while the official generic drugs are those sold under the generic names of the drugs with a special logo on the drug packages. A special regulation from the government is applied to this official generic drug. Thus, the term "generic drugs" in Indonesia, and in the present study as well, refer to not only the official generic but also to branded drugs other than the innovator products. As a consequence, this may contribute to a variation in the National Drug Policy for pharmaceutical manufacturers, especially when submitting a new application for their generic products [31]. Therefore, this disparity may contribute to the varying performance of the generic drugs, especially when compared to the innovator product.

The innovator drug is often believed to exhibit better quality than the generic products, as the generic drugs are thought to have lower performance. These perceptions are very common in both consumers and health-care practitioners, including pharmacists. This is predominantly due to limited and wrong information about the generic drugs. Unfortunately, this perception causes an impact on the attitude of society, both health-care practitioners and consumers, concerning the use of generic drug products $[15,32,33]$. The low acceptance of the patients to receive generic products after using the branded drugs is also reported [34]. However, this phenomenon can, sometimes, be justified since many studies have confirmed significant differences in terms of pharmacokinetic profile or pharmacological effect between branded and generic drugs $[7,35]$. The low quality of the generic drugs is reported to attenuate not only the efficacy of the drug but also their tolerability and safety that may lead to hospital admission [36,37].

It is plausible that a number of limitations in the present study are worth considering to not generalize the findings, especially in comparing the overall quality of innovator versus generic drugs. First, the study investigated only three different MP tablets representing three classes of drug classification concerning the brand-generic issue. There was no description of the pharmaceutical ingredients of the formulations, including the composition of the excipients. In addition, the determination of serum concentration of AnxA1 as the sole biochemical parameter might not necessarily represent the whole quality of the drugs, especially its efficacy. At last, the pharmacological effect of the drug, which is in this case to reduce the inflammation, was not investigated. Nevertheless, the claim about the equivalent performance between innovator, branded, and generic drugs should be addressed carefully and responsibly. The regulators are encouraged to appropriately maintain the criteria to evaluate the bioequivalence studies in the approval of generic drug formulations to guarantee the therapeutic equivalence to their innovator products [16]. 


\section{CONCLUSION}

The study concludes that the innovator drug of MP exhibits a significantly higher serum concentration of AnxA1 as compared with its branded generic and generic tablets. The comparative profile of AnxA1 shows that the innovator drug demonstrates higher $\mathrm{C}_{\text {max' }}$, faster $\mathrm{T}_{\text {max' }}$ and larger AUC than its generic counterparts. The study suggests that the innovator drug of MP is likely to produce the same pharmacological effect than its generic products.

\section{ACKNOWLEDGMENT}

We would like to show our gratitude to the Faculty of Pharmacy for supporting us with research funding with Contract Number: 23/ UN.16.10/DPPKM/FFARMASI/2018.

\section{AUTHORS' CONTRIBUTIONS}

Hansen Nasif: Responsible for conceptualization, resources, funding acquisition, methodology, laboratory experiments, formal analysis, original draft preparation, and visualization. Henny Lucida: Responsible for conceptualization, methodology, validation, and supervision. Yanwirasti: Responsible for conceptualization, methodology, validation, and supervision. Yufri Aldi: Responsible for conceptualization, methodology, validation, and supervision. Yori Yuliandra: Responsible for software, original draft preparation, validation, review, and editing.

\section{CONFLICTS OF INTEREST}

All authors declare that they have no conflicts of interest.

\section{REFERENCES}

1. Association for Accessible Medicines. 2017. Generic Drugs Access and saving in the U.S. Available from: http://www.bit.ly/2tv5gzY. [Last accessed on 2018 May 18]

2. Wouters OJ, Kanavos PG, McKEE M. Comparing generic drug markets in Europe and the United States: Prices, volumes, and spending. Milbank Q 2017;95:554-601

3. Colombo GL, Montecucco CM. Generic vs. brand originator alendronate: Analysis of persistence and compliance in five local healthcare units in the Lombardy region of Italy. Clin Cases Miner Bone Metab 2013;10:195-8.

4. Takizawa O, Urushihara H, Tanaka S, Kawakami K. Price difference as a predictor of the selection between brand name and generic statins in Japan. Health Policy 2015;119:612-9.

5. Sukapti S, Dwiyanti D. Generic drug prescribing and its influencing factors at outpatients departments in some government hospitals in West Sumatra, Indonesia. Andalas J Public Heal 2010;5:21-7.

6. Brown JP, Davison KS, Olszynski WP, Beattie KA, Adachi JD. A critical review of brand and generic alendronate for the treatment of osteoporosis. Springerplus 2013;2:550.

7. Del Tacca M, Pasqualetti G, Di Paolo A, Virdis A, Massimetti G, Gori $\mathrm{G}$, et al. Lack of pharmacokinetic bioequivalence between generic and branded amoxicillin formulations. A post-marketing clinical study on healthy volunteers. Br J Clin Pharmacol 2009;68:34-42.

8. Garg G, Gogia A, Kakar A. Comparison of the acute side effect profile of zoledronic acid innovator versus generic preparation. Curr Med Res Pract 2016;6:181-3.

9. Diaz JA, Silva E, Arias MJ, Garzón M. Comparative in vitro study of the antimicrobial activities of different commercial antibiotic products of vancomycin. BMC Clin Pharmacol 2011;11:9.

10. Cooper-DeHoff RM, Elliott WJ. Generic drugs for hypertension: Are they really equivalent? Curr Hypertens Rep 2013;15:340-5.

11. Zaid AN, Al Ramahi R, Bustami R, Mousa A, Khasawneh S. Comparative fasting bioavailability of two clopidogrel formulations in healthy mediterranean volunteers: An in vitro-in vivo correlation. Drug Des Devel Ther 2015;9:2359-65.

12. Tjandrawinata RR, Setiawati E, Yunaidi DA, Simanjuntak R, Santoso ID, Susanto LW, et al. Bioequivalence study of two formulations of candesartan cilexetil tablet in healthy subjects under fasting conditions. Drug Des Devel Ther 2013;7:841-7.

13. Ramamoorthy S, Cidlowski JA. Corticosteroids: Mechanisms of action in health and disease. Rheum Dis Clin North Am 2016;42:15-31, vii.

14. Toverud EL, Hartmann K, Håkonsen H. A systematic review of physicians' and pharmacists' perspectives on generic drug use: What are the global challenges? Appl Health Econ Health Policy 2015;13 Suppl 1:S35-45.

15. Babar ZU, Stewart J, Reddy S, Alzaher W, Vareed P, Yacoub N, et al. An evaluation of consumers' knowledge, perceptions and attitudes regarding generic medicines in Auckland. Pharm World Sci 2010;32:440-8.

16. Davit BM, Nwakama PE, Buehler GJ, Conner DP, Haidar SH, Patel DT, et al. Comparing generic and innovator drugs: A review of 12 years of bioequivalence data from the united states food and drug administration. Ann Pharmacother 2009;43:1583-97.

17. Arafat MA, Ahmed Z, Arafat O. Comparison between generic drugs and brand name drugs from bioequivalence and thermoequivalence prospective. Int J Pharm Pharm Sci 2017;9:1-4.

18. Yazid S, Ayoub SS, Solito E, McArthur S, Vo P, Dufton N, et al. Anti-allergic drugs and the annexin-A1 system. Pharmacol Rep 2010;62:511-7

19. Yazid S, Norling LV, Flower RJ. Anti-inflammatory drugs, eicosanoids, and the annexin A1/FPR2 anti-inflammatory system. Prostaglandins Other Lipid Mediat 2012;98:94-100

20. Yu LX, Amidon GL, Polli JE, Zhao H, Mehta MU, Conner DP, et al. Biopharmaceutics classification system: The scientific basis for biowaiver extensions. Pharm Res 2002;19:921-5.

21. Dressman JB, Reppas C. In vitro-in vivo correlations for lipophilic, poorly water-soluble drugs. Eur J Pharm Sci 2000;11 Suppl 2:S73-80.

22. Flower RJ, Blackwell GJ. Anti-inflammatory steroids induce biosynthesis of a phospholipase A2 inhibitor which prevents prostaglandin generation. Nature 1979;278:456-9.

23. Minghetti L, Nicolini A, Polazzi E, Greco A, Perretti M, Parente L, et al. Down-regulation of microglial cyclo-oxygenase-2 and inducible nitric oxide synthase expression by lipocortin 1 . Br J Pharmacol 1999; $126: 1307-14$

24. Perretti M, D'Acquisto F. Annexin A1 and glucocorticoids as effectors of the resolution of inflammation. Nat Rev Immunol 2009;9:62-70.

25. Sheikh MH, Solito E. Annexin A1: Uncovering the many talents of an old protein. Int J Mol Sci 2018;19: E1045.

26. Rhen T, Cidlowski JA. Antiinflammatory action of glucocorticoids new mechanisms for old drugs. N Engl J Med 2005;353:1711-23.

27. Khan AN, Khar RK, Udayabanu M. Quality and affordability of amoxicillin generic products: A patient concern. Int J Pharm Pharm Sci 2016;8:386-90.

28. Zarmpi P, Flanagan T, Meehan E, Mann J, Fotaki N. Biopharmaceutical aspects and implications of excipient variability in drug product performance. Eur J Pharm Biopharm 2017;111:1-5.

29. Thakkar PH. Influence of excipients on drug absorption via the modulation of intestinal transporters activity. Asian $\mathrm{J}$ Pharm 2015;9:69-82.

30. US Food and Drug Administration. Abbreviated New Drug Application. 2018. Available from: https://www.fda.gov/Drugs/ DevelopmentApprovalProcess/HowDrugsareDevelopedandApproved/ ApprovalApplications/AbbreviatedNewDrugApplicationANDAGenerics/ default.htm. [Last accessed 2018 May 20].

31. Alfonso-Cristancho R, Andia T, Barbosa T, Watanabe JH. Definition and classification of generic drugs across the world. Appl Health Econ Health Policy 2015;13 Suppl 1:S5-11.

32. Chong CP, Hassali MA, Bahari MB, Shafie AA. Evaluating community pharmacists' perceptions of future generic substitution policy implementation: A national survey from Malaysia. Health Policy 2010;94:68-75.

33. Chua GN, Hassali MA, Shafie AA, Awaisu A. A survey exploring knowledge and perceptions of general practitioners towards the use of generic medicines in the northern state of Malaysia. Health Policy 2010;95:229-35.

34. Molinier A, Palmaro A, Rousseau V, Sommet A, Bourrel R, Montastruc JL, et al. Does substitution of brand-name medications by generics differ between pharmacotherapeutic classes? A populationbased cohort study in France. Eur J Clin Pharmacol 2017;73:471-7.

35. Sun D, Hu M, Browning M, Friedman RL, Jiang W, Zhao L, et al. Dissolution failure of solid oral drug products in field alert reports. J Pharm Sci 2017;106:1302-9.

36. Hsu CW, Lee SY, Wang LJ. Comparison of the effectiveness of brand-name and generic antipsychotic drugs for treating patients with schizophrenia in Taiwan. Schizophr Res 2018;193:107-13.

37. Faqeer NA, Mashni O, Dawoud R, Rumman A, Hanoun E, Nazer L, et al. Comparing the incidence of febrile neutropenia resulting in hospital admission between the branded docetaxel and the generic formulations. J Clin Pharmacol 2017;57:275-9. 